\title{
„Czasem aż boję się koledzy, że na obrazy \\ z telewizorem nie wygramy". \\ Artystyczna odpowiedź na tęsknotę człowieka współczesnego za żywym doświadczeniem
}

\begin{abstract}
Streszczenie
Artykuł jest prezentacją współczesnych działań artystycznych, które mogą być postrzegane jako odpowiedź na tęsknotę współczesnego człowieka za żywym doświadczeniem. Odbiorcy pogrążeni w wirtualnym świecie mediów społecznościowych, twitterowych dialogów, w kulturze nadmiaru i nadobecności obrazów poszukują wizualnej ciszy. Komunikacja zapośredniczona medialnie wzmaga potrzebę kontaktu z „żywym” człowiekiem. Z drugiej strony zaś współczesny odbiorca, przyzwyczajony do aktywnego bycia w świecie, tego samego oczekuje od sztuki. Sztuka musi „się dziać”, aby przyciągnąć uwagę. Punktem centralnym procesu twórczego przestaje być dzisiaj niezależne dzieło sztuki (tworzone przez artystę - interpretowane przez odbiorcę), a staje się nim wydarzenie, które powstaje, trwa/ rozwija się i kończy w wyniku działań wszystkich podmiotów zaangażowanych w proces: zarówno artysty/artystów, jak i odbiorcy/odbiorców. Wyraźnie dziś widoczne jest przeniesienie uwagi z „uprawiania sztuki” na „doświadczanie sztuki”. Odpowiedzią na potrzeby współczesnego odbiorcy mogą być projekty artystyczne związane ze zwrotem performatywnym, ze sztuką partycypacyjną, sztuką społeczności, a także sztukq-jako-pedagogi$k q$. W artykule omówione zostały wybrane projekty artystyczne należące do powyższych kategorii, w kontekście ich pedagogicznego potencjału.
\end{abstract}

1 Barbara Kwiatkowska-Tybulewicz, Wydział Pedagogiczny, Uniwersytet Warszawski, e-mail: b.kwiatkowska@uw.edu.pl, ORCID ID: https://orcid.org/0000-0002-8927-8943. 


\title{
Słowa kluczowe:
}

sztuka, pedagogika, zwrot performatywny, sztuka partycypacyjna, sztuka-jako-pedagogika

\begin{abstract}
The article is a presentation of contemporary artistic activities that can be seen as a response to the longing of a modern man for a living experience. Recipients, immersed in the virtual world of social media, twitter dialogues, in the culture of excess and the over-presence of images, are looking for a visual silence. Media-mediated communication increases the need for contact with a ,living” person. On the other hand, a contemporary recipient, accustomed to being active in the world, expects the same from art. Art must „be happening” to attract attention. Today the focal point of the creative process ceases to be an independent work of art (created by an artist - interpreted by a recipient), and becomes an event that creates, continues / develops and ends as a result of the activities of all actors involved in the process: both the artist / artists, and recipient / recipients. You can see clearly today the shift of attention from „practicing art” to „experiencing art”. The response to the needs of a contemporary recipient can be projects related to performative turn, participatory art, community art and also artas-pedagogy. The article discusses selected artistic projects belonging to the above categories, in the context of their pedagogical potential.
\end{abstract}

\section{Keywords:}

art, pedagogy, performative turn, participatory art, art-as-pedagogy

\section{WPROWADZENIE: NADOBECNOŚĆ OBRAZÓW}

Paweł Susid, współczesny artysta, którego obrazy przyjmują formę komunikatów będących swoistym połączeniem formy plastycznej i słowa, w 2000 roku wyraził na jednym ze swoich dzieł obawę o przyszłość sztuki (konkretnie malarstwa) w kontekście konkurencji masowych środków przekazu. Ironiczna i gorzka refleksja nad obrazem jest widoczna nie tylko w pracy „Czasem aż boję się koledzy, że na obrazy z telewizorem nie wygramy” (2000), ale także w innych malarsko-poetyckich realizacjach artysty, w których twórca poddaje refleksji miejsce i recepcję obrazu w przesyconej komunikatami wizualnymi współczesności. „Obrazosłowa” artysty to komentarze opisujące i komentujące rzeczywistość, będące celną, często ironiczną puentą dotyczącą zjawisk i sytuacji, których doświadcza odbiorca, oraz przyzwyczajeń, którym ulega. Jednocześnie daleko artyście do pretensjonalności 
i moralizatorstwa, gdyż jego komentarz do dzisiejszej sytuacji społeczno-politycznej jest rodzajem zabawnej gry słownej kierowanej do odbiorcy.

Odwołanie się we wstępie do obrazu Susida jest o tyle zasadne, iż we współczesnej kulturze cała rzeczywistość staje się obrazem. Zarówno spektakularność społeczeństwa opisywana przez Deborda, jak i panoptyczność nadzoru analizowana przez Foucaulta dają się wpisać we współczesne strategie konstruowania kultury obrazu, funkcjonującej na wszystkich poziomach doświadczenia człowieka końca XX i początku XXI wieku. Obrazy zastępują dziś rzeczywistość, będąc „pożądanymi namiastkami doświadczeń bezpośrednich, stają się niezbędne dla zdrowej gospodarki, stabilizacji politycznej i poszukiwania szczęścia przez każdego z nas” (Sontag, 2009, s. 162). Na gruncie polskim specyficznej rewolucji obrazowej doświadczyliśmy około trzy dekady temu, kiedy to rozpoczął się radykalny ruch obrazów z przestrzeni prywatnej do publicznej. Widocznym znakiem transformacji ustrojowej w Polsce w 1989 roku było gwałtowne rozprzestrzenienie się nowych typów i gatunków obrazowych, takich jak reklama telewizyjna czy plakat wielkoformatowy, oraz pojawienie się instytucji z nimi związanych: telewizji komercyjnych, licznych magazynów ilustrowanych itp. (Szcześniak, 2016, s. 32). Według Łukasza Zaremby to właśnie inwazja obrazów komercyjnych w przestrzeni publicznej, ich nadmierna obecność w miejskim krajobrazie, jest oznaką pewnego przełomu w świecie obrazów, do którego doszło w naszym kraju w latach 90. XX wieku. Warto zauważyć, że obrazy/ekrany wpłynęły także istotnie na przestrzeń prywatną, rearanżując obszar naszych mieszkań oraz zmieniając poczucie upływu czasu, ale to ich obecność w przestrzeni publicznej jest oznaką rewolucji obrazowej, jaka dokonała się na koniec XX wieku w Polsce (Zaremba, 2017, s. 20). Żyjąc w kulturze nadmiaru (por. Szlendak, 2013), odczuwamy nadobecność obrazów, która powoduje, iż przebywając na co dzień w przestrzeni prywatnej i publicznej - ikonicznie zakrzyczanej - tęsknimy za wizualną ciszą (Szlendak, 2013, s. 9). Wracając w tym kontekście do stwierdzenia Susida, warto zastanowić się, czy sztuka może w jakiś sposób odpowiedzieć na tę nową nadmiarową wizualnie rzeczywistość. Czy odbiorcy/widzowi, bombardowanemu ze wszystkich stron obrazami, udaje się skutecznie skupić na kolejnych wizerunkach pokazywanymi w galerii sztuki? A może współczesny odbiorca sztuki poszukuje w niej czegoś innego, bardziej realnego, związanego z żywym doświadczeniem? Obserwując wnikliwie zmiany, jakie dokonują się we współczesnym świecie sztuki, można zaryzykować twierdzenie, że dzisiejszy odbiorca szuka w sztuce nie tylko intelektualnych inspiracji, ale także fizycznych doświadczeń. Niekoniecznie kolejnych obrazów, ale bardziej kontaktu z „żywym” człowiekiem. 


\section{SZTUKA PARTYCYPACYJNA: OD WIDZA DO UCZESTNIKA}

W ostatnich latach w sztuce współczesnej zaobserwowano kilka „zwrotów”: zwrot performatywny, zwrot społeczny, zwrot kinematograficzny, zwrot dokumentalny. Pod koniec XX wieku znacznie wzrosło zainteresowanie artystów praktykami partycypacji i współpracy. Do lat 90. sztuka zainteresowana społecznością ograniczała się do peryferii świata sztuki, zaś od końca ubiegłego wieku ten rodzaj sztuki funkcjonuje oficjalnie pod wieloma nazwami: sztuki zaangażowanej społecznie, sztuki społeczności, sztuki dialogicznej, wspólnot eksperymentalnych, sztuki pobrzeżnej, sztuki partycypacyjnej, sztuki interwencjonistycznej, sztuki kolaboratywnej/opartej na współpracy czy po prostu praktyki społecznej (Bishop, 2015, s. 17-18). Dzisiejsza sztuka partycypacyjna (aby trzymać się jednego określenia używanego przez Claire Bishop) podkreśla przewagę procesu nad konkretnym obiektem, obrazem lub koncepcją. Tendencję przekierowania uwagi od dzieła/ produktu ku procesowi twórczemu widać nie tylko w przestrzeni sztuki, ale także w innych dziedzinach. Jak zauważa Jon McKenzie (2011), nie jest od niej wolna współczesna antropologia, zwracająca się od struktur mitycznych ku ich ucieleśnieniu w rytuałach, czy etnografia przenosząca uwagę z tekstu na kontekst opowiadania. W językoznawstwie zaś zaobserwować można podobny kierunek w przesunięciu od struktur gramatycznych (langue) ku analizie pragmatyki wypowiedzi (parole). Tym samym w szerokim zakresie praktyk kulturowych widać zwrot od zapośredniczonego wyrazu do bezpośredniego kontaktu, od reprezentacji do prezentacji czy od nieobecności do obecności (McKenzie, 2011, s. 48).

W związku z opisaną wyżej tendencją, współcześni artyści związani ze sztuką partycypacyjną wydają się bardziej cenić to, co „niewidzialne”: konkretną sytuację społeczną, poziom świadomości czy dynamikę grupy, niż artefakt, wytwór, obiekt, obraz. Tego typu działania artystyczne sytuują sztukę w optyce osobistego doświadczenia ludzkiego, usytuowanego w perspektywie dłuższego trwania, czym znacznie zwiększają wymaganie zaangażowania czasowego w porównaniu ze sztuką, do której przywykł już odbiorca (Bishop, 2015, s. 25). Sztuka zajmująca się społeczeństwem i funkcjonującymi w jego obrębie ludźmi jest szczególnie interesująca dla pedagogów między innymi z tego powodu, iż analizowanie tego typu projektów wymaga zaangażowania naukowców także z nauk społecznych (a do nich przecież należy pedagogika) i oparcia się na koncepcjach dotyczących społeczeństwa, wspólnotowości, sprawczości, upodmiotowienia, inkluzji/ekskluzji itd. Jak podkreśla Bishop „Metodologiczny aspekt »zwrotu społecznego« jest jednym z wyzwań, przed którymi stają historycy sztuki i krytycy zajmujący się poszerzonym polem sztuki współczesnej. Artystyczna partycypacja domaga się 
nowych sposobów analizowania sztuki, które nie będą już związane wyłącznie z wizualnością, nawet jeśli najważniejszym medium komunikowania pozostaje forma” (Bishop, 2015, s. 27). Sztuka partycypacyjna może być zatem tą formą działań z odbiorcą, która odpowie na potrzebę ,uczestniczenia w czymś”, a nie tylko „oglądania czegoś”. Współczesny artysta jest w mniejszym stopniu twórcą obiektu, a bardziej współpracownikiem i wytwórcą sytuacji będącej rozciągniętym w czasie projektem, z często niesprecyzowanym początkiem i zakończeniem. Publiczność zaś, postrzegana wcześniej jako widz/obserwator, zostaje teraz sprowadzona do roli współtwórcy/uczestnika (Bishop, 2015, s. 19).

\section{ART-AS-PEDAGOGY: NA STYKU SZTUKI I PEDAGOGIKI}

Z wyróżnionych przez Bishop (2015, s. 23) dwóch modeli partycypacji: performans delegowany (w imieniu artysty występują wynajęci ludzie) oraz projekty pedagogiczne (sztuka zbiega się z działaniami i metodami o charakterze edukacyjnym), szczególnie interesujący z perspektywy pedagogicznej jest model drugi. W XXI wieku obserwujemy wzrost liczby projektów pedagogicznych podejmowanych przez artystów, w których ma miejsce wykorzystanie określonych metod i form edukacyjnych, np.: wykładów, warsztatów, publikacji czy seminariów itp. Irit Rogoff używa w tym kontekście pojęcia ,zwrot edukacyjny w sztukach i praktykach kuratorskich” (Rogoff, 2008). Określenie „educational turn” czy „pedagogical turn” coraz częściej pojawia się w tekstach naukowych, debatach, wystąpieniach konferencyjnych dotyczących poszerzania pola sztuki współczesnej o przestrzeń pedagogiczną (por. O’Neill and Wilson, 2010, Atkinson 2011, s. 134). Artystami-prekursorami pracy na pograniczu sztuki i pedagogiki są: Luis Camnitzer, Joseph Beuys, Lygia Clarc, Jef Geys czy Tim Rollins. Wśród młodszego pokolenia warto nadmienić: Tanię Bruguerę, Thomasa Hirschorna czy Pawła Althamera. Wymienieni artyści podjęli się działań artystyczno-pedagogicznych w różnych formach, ale zawsze kładących nacisk na rolę uczestnika w procesie twórczym.

Tania Bruguera założyła specyficzną uczelnię artystyczną Cátedra Arte de Conducta (2002-2009) działającą jako półautonomiczny moduł pod auspicjami Instituto Superior de Arte w Hawanie. Bruguera zapraszała artystów z różnych krajów w charakterze wykładowców, którzy pracowali ze studentami. Wśród zaproszonych znalazł się m.in. polski artysta Artur Żmijewski. W kursach uczestniczyli także: kuratorzy i teoretycy sztuki, socjologowie, matematycy, prawnicy czy dziennikarze, którzy traktowali całe miasto jako bazę operacyjną. Celem takiej formy edukacji (odbywającej się tak w przestrzeni całego miasta, jak i w domu 
artystki) miało być „stworzenie przestrzeni wolnej wypowiedzi w opozycji do dominującej władzy (...) i przygotowanie studentów do aktywności, która nie ograniczałaby się do pracy twórczej, lecz dotyczyła także doświadczania i formułowania zasad rządzących społeczeństwem obywatelskim” (Bishop, 2015, s. 428).

Thomas Hirschorn z kolei realizuje projekty społeczne na wielką skalę, przy współudziale mieszkańców konkretnego obszaru miasta, w których coraz ważniejszą rolę odgrywa komponent pedagogiczny. Wzorcowym przykładem zrealizowanego projektu artystyczno-pedagogicznego może być Musée Précaire Albinet (2004) w paryskiej dzielnicy Aubervilliers. Mieszkańcy, wspólnie z artystą, przygotowywali siedem tygodniowych wystaw złożonych z prac wypożyczonych z Centrum Pompidou, uzupełnionych bogatym programem wydarzeń towarzyszących: w poniedziałki instalowanie prac, we wtorki wernisaże, we środy atelier pour enfants (działania dla dzieci), we czwartki warsztaty pisarskie dla dorosłych, w piątki debaty, w soboty dyskusje z historykami i krytykami sztuki. W niedziele zaś odbywał się wspólny obiad przygotowywany przez jedną z uczestniczących $\mathrm{w}$ wydarzeniu rodzin lub grup. Istotnym elementem tak realizowanego projektu na styku sztuki i pedagogiki było to, że w działaniach przygotowywanych przez artystę i mieszkańców dzielnicy uczestniczyli okoliczni sąsiedzi. Projekt z założenia przeznaczony był nie dla „znawców sztuki”, ale lokalnych bywalców, a funkcją wykładów i realizowanych działań nie był transfer informacji, a raczej wspólne doświadczenie, które łączyło przedstawicieli różnych grup. (Bishop, 2015, s. 445-446).

Szukając podobnych przykładów działania na styku sztuki i pedagogiki w naszej polskiej rzeczywistości, uwagę przykuwa Klasa Einsteina Pawła Althamera (2005). Althamer to artysta, o którego sztuce Karol Sienkiewicz pisze tak: „Lepiej chodzić w pejzażu i oglądać go 1:1, niż go malować. Lepiej podejść do modela i porozmawiać z nim, niż go rzeźbić. Nie delektować się dokumentacją, tylko doświadczać »tu i teraz«. Po prostu - życie. Jedno z wielu” (Sienkiewicz, 2017, s. 43). Klasa Einsteina doskonale do powyższego opisu pasuje. Artysta zainicjował półroczny projekt kółka fizycznego dla siedmiu chłopców z warszawskiej Pragi. Zajęcia prowadzone były przez trzech fizyków pasjonatów wybranych przez artystę. Podczas cyklicznych spotkań młodzi uczestnicy - mieszkańcy warszawskiej Pragi - zapoznani zostali z wieloma eksperymentami naukowymi. Całość przybrała formę edukacji nieformalnej - nauki przez zabawę, skupiając się na utrzymaniu ciekawości i zainteresowaniu młodzieży zjawiskami fizycznymi, możliwymi do zaobserwowania w ich codziennym otoczeniu. Eksperymenty odbywały się w różnych miejscach w Warszawie, tak w przestrzeni publicznej, jak i prywatnej (pracowni artysty czy ogrodzie nauczyciela). W ramach projektu odbył 
się także kilkudniowy wyjazd nad morze, gdzie młodzi uczestnicy obserwowali przez teleskop gwiazdy i przeprowadzali przeróżne doświadczenia. W drugiej fazie projektu chłopcy zorganizowali na jednym z praskich podwórek piknik naukowy, podczas którego zademonstrowali poznane eksperymenty swoim sąsiadom. Kontynuację procesu edukacyjnego stanowiła wizyta uczestników projektu w Berlinie na wernisażu wystawy pokazującej dokumentację ze zrealizowanego działania.

Bishop, pisząc o sztuce-jako-pedagogice, podkreśla, że projekty pedagogiczne, jako działania transdyscyplinarne, unaoczniają relacje między polem sztuki a polem społecznym, poddając próbom i rewizjom kryteria i przekonania, jakich używamy względem obu dziedzin, oraz zmuszając do rozważania zarówno cech wspólnych, jak i odróżniających oba pola, w których art-as-pedagogy jest usytuowana. „Dla nas samych (...) najistotniejszym aspektem edukacyjnym takich projektów może być konieczność myślenia o obu tych polach jednocześnie oraz tworzenia nowych, adekwatnych języków i kryteriów, dzięki którym możliwe stanie się komunikowanie praktyk transwersalnych” (Bishop, 2015, s. 466). Rozważając projekty sztuki-jako-pedagogiki z perspektywy pedagogicznej warto zastanowić się nad tym, czego edukator/pedagog może nauczyć się od artystów w kontekście praktyki pedagogicznej? Odpowiedź na to pytanie daje między innymi Elliot W. Eisner (2004). Nie wnikając w tym miejscu w dokładną analizę tego zagadnienia dokonaną przez Eisnera, warto zwrócić uwagę na podkreślany przez niego potencjał sztuki do zmieniania naszego sposobu myślenia o świecie i edukacji - w uświadamianiu nam, pedagogom, że szkoła i działanie edukacyjne mogą wyglądać zupełnie inaczej niż funkcjonujący obecnie w naszej świadomości społecznej obraz instytucji edukacyjnej. To dzięki działaniom artystycznym możemy zweryfikować nasze zdanie na temat tego, czym, po co i dla kogo jest szkoła. Poza tym sposoby myślenia, które inspiruje, kształtuje i do których zachęca sztuka, są znacznie bardziej przydatne we współczesnej, zmiennej rzeczywistości niż tradycyjne uporządkowane systemy myślenia i działania, propagowane w edukacji szkolnej.

\section{SOMATYCZNE ZAANGAŻOWANIE ODBIORCY/UCZESTNIKA}

Działania współczesnych artystów zmierzające do zaangażowania odbiorcy nie ograniczają się tylko do projektów społecznych, ale przybierają także formę działań skupionych na somatycznym włączeniu uczestnika w przestrzeń sztuki. Dziś sztuka może wyglądać jak impreza techno, bar czy sala fitness - im mniej przypomina tradycyjną sztukę, tym lepiej (Szabłowski, 2017). Dla dbiorcy ważny staje się bez- 
pośredni kontakt z artystą, który występuje dzisiaj w roli nie tylko performera, ale także trenera.

Performatywny zwrot, który zauważalny jest w sztuce od lat 60. i 70. XX wieku, doprowadził do zasadniczych zmian w obrębie poszczególnych sztuk, oraz umożliwił powstanie nowego gatunku artystycznego performansu. Pojawiła się tendencja, aby zamiast dzieł/artefaktów tworzyć wydarzenia, w których albo sam artysta prezentuje się przed publicznością, albo angażuje odbiorców, którzy wychodzą z roli widzów i biorą aktywnie udział w przedstawieniu. Od tego momentu zasadniczo zmieniły się warunki tworzenia i odbioru sztuki. Punktem centralnym procesu twórczego przestało być niezależne dzieło sztuki (stanowiące przedmiot kreatywnej działalności artysty oraz percepcji i interpretacji odbiorcy), a stało się nim wydarzenie, które powstaje, trwa/rozwija się i kończy w wyniku działań wszystkich podmiotów - zarówno artysty, jak i odbiorcy (Fischer-Lichte, 2008, s. 29). Wiązało się to także z przeniesieniem uwagi z „uprawiania sztuki” na „doświadczanie sztuki”. Od lat 90. podejście performatywne rozszerzyło się na całą kulturę, która przestała być utożsamiana metaforycznie z tekstem, a zaczęła z performansem. Koncepcja kultury odziedziczona po XIX stuleciu, traktująca kulturę (całościowo) oraz pojedyncze zjawiska życia kulturalnego jako skomplikowane struktury znaków - teksty wymagające rozszyfrowania, opisania i wyłożenia ich sensów, zaczęła być kwestionowana. Punkt ciężkości przesunął się z tekstów na „wydarzenie” - w centrum uwagi znalazły się performatywne cechy kultury. Od tego momentu mówimy z jednej strony o kulturze jako performansie (Fischer-Lichte, 2008, s. 36), z drugiej zaś uznajemy performans za podstawowy zabieg w procesie budowania kultury i jej związku z innymi kulturami (Carlson, 2007, s. 259). Przesunięcie różnych obszarów kulturowych od „,co” do „jak”, od gromadzenia danych kulturowych, społecznych, psychologicznych itp. do rozważania, w jaki sposób ten materiał się tworzy, zmienia i ocenia, jak działa on w kulturze, nabiera szczególnej wagi w czasach powszechnego zainteresowania kulturowymi negocjacjami, czyli sposobami ustanawiania i zmieniania w kulturze wzorców ludzkich zachowań i dopasowywaniem ich w interakcji pomiędzy odmiennymi kulturami (Carlson, 2007, s. 304).

Ucieczka sztuki współczesnej od tradycyjnie kojarzonej ze sztuką formy wystawy prac plastycznych (obrazów/rzeźb) - jest symptomem zmian, jakie dokonują się obecnie w naszej kulturze. Od momentu zwrotu performatywnego prace artystów częściej się w muzeum „dzieją” niż po prostu „są wystawiane”. Dzisiaj obserwujemy jednak coś, co można nazwać kolejnym krokiem na drodze wskazanej przez zwrot performatywny - mariaż kultury artystycznej z kulturą fizyczną (Szabłowski, 2017). Jako egzemplifikacja tej nowej tendencji niech 
posłuży wystawa „Lepsza ja”, mająca miejsce latem 2017 roku w warszawskiej Zachęcie. Jak można było przeczytać w opisie wystawy zamieszczonym na stronie galerii „Wystawa (...) składa się z działań, performansów, treningów i warsztatów z udziałem publiczności, a jej przestrzeń stanie się sceną, siłownią, salą do jogi i gabinetem terapeutycznym oraz miejscem rozmowy. Sale galerii nie będą służyć prezentacji obiektów sztuki, wypełnią je ludzie i działania” (Lepsza ja, 2017). Publiczność miała szansę wziąć udział w treningach jogi, konsultacjach dietetycznych Niny Cristante, terapii Jennifer Lacey, performansach choreografek z Centrum w Ruchu czy w warsztatach skakania z Pawłem Sakowiczem. Ponadto w przestrzeni sztuki można było doświadczyć sesji hipnozy Xavier Cha. To, co się dzieje we współczesnej sztuce, wyraźnie pokazuje, że dzisiejszej publiczności nie wystarczy już oglądanie artystów/performerów w akcji. Odbiorca XXI wieku sam chce działać w przestrzeni sztuki, czując, że głównymi bohaterami muzeum/ galerii sztuki nie są już dzieła, a odbiorcy/uczestnicy.

Funkcjonujące dawniej określenie o wyraźnym zabarwieniu pejoratywnym: „kultura - ale tylko fizyczna!” nie daje się więc już dzisiaj utrzymać. Kultura artystyczna i fizyczna stworzyły w przestrzeni sztuki współczesnej ciekawą hybrydę. Widok biegnących truchtem po salach wystawowych ludzi, robiących przysiady, pajacyki czy inne ćwiczenia fizyczne, dziwi już coraz mniej. Tego typu zjawiska zaobserwować można w najważniejszych muzeach świata. „Museum workout” w Metropolitan Museum w Nowym Jorku to program zwiedzania kolekcji MET połączony z ćwiczeniami fizycznymi. Prowadzą go performerki z zespołu Monica Bill Barbes \& Company. Taka artystyczno-fizyczna forma zwiedzania cieszy się bardzo dużą popularnością. Podobnie w londyńskim Victoria \& Albert Museum organizowane są poranki z jogą, w czasie których odbiorcy biorą udział w „zdrowym zwiedzaniu” kolekcji. Mariaż formy artystycznej i fizycznej widać także na największych współczesnych imprezach artystycznych. Podczas ostatniego Biennale w Berlinie w Akademii Sztuk przy placu Paryskim publiczności zaproponowano zestaw drabinek gimnastycznych do crossfitu „Open Workout”, stworzony przez artystę Nika Kosmasa. Udział w treningach na wystawie okazał się jeszcze jedną formą uczestnictwa w biennale. Jedną z artystek zaproszonych do poprowadzenia treningu w „Open Workout” była Helga Wretman, artystka wizualna, tancerka, trenerka i kaskaderka fimowa. Wretman jest przykładem współczesnych artystów poszerzających pole sztuki o działania somatyczne. Jej projekt „Fitness dla artystów”, czyli kanał na YouTubie, a także cykl performatywnych treningów to próby zerwania ze stereotypem artysty jako człowieka o dekadenckich skłonnościach, prowadzącego najprawdopodobniej niezdrowy tryb życia. Według Wretman to właśnie ćwiczenia fizyczne i doskonalenie własnego ciała mają wyzwolić twórczy 
potencjał ludzi sztuki (artystów/odbiorców). Inną artystką prowadzącą działania fizyczne w przestrzeni „Open Workout” była Nina Cristante (wymieniona już przy okazji wystawy „Lepsza ja”), związana zarówno ze sztuką wideo, rzeźbą czy fotografią, jak również z eklektycznymi planami treningowymi i spersonalizowanymi „artdietami”. Berlińskie Biennale kuratorowane przez DIS to idealny przykład dzisiejszych kulturowych tendencji. Kuratorzy berlińskiej imprezy jako osiągnięcie przedstawiali fakt, iż udało im się zrobić Biennale, na którym znalazł się tylko jeden obraz sztalugowy (Szabłowski, 2017). Poza tym sam Kosmas, ogłaszający, że nie jest już jedynie „,artystą”, a przedstawiający się jako „trener osobisty”, staje się symptomem nadchodzących zmian. Co ciekawe jego drabinka do ćwiczeń trafiła do kolekcji Muzeum Sztuki Nowoczesnej w Warszawie i została ustawiona w Parku Rzeźby na Bródnie. Jak podkreśla Szabłowki (2017) „Jedną z zalet tej pracy - oprócz wszystkiego innego, choćby ewokowania refleksji na temat kultury indywidualizmu, z jej koncentracją na zdrowiu i ulepszaniu samego siebie - jest to, że naprawdę można sobie na niej poćwiczyć”.

Opisane wyżej przykłady, poza tym, że wyraźnie odwołują się do doświadczenia, są dowodem na trwający już od XX wieku proces zbliżania się sztuki i życia. Nowe formy sztuki są odpowiedzią na znane nam z codzienności warsztaty samodoskonalenia się, hipnoterapie, terapie tańcem i ruchem, coaching, zajęcia z relaksacji, kursy pracy nad świadomością własnego ciała, fitness i inne tego typu modne dziś aktywności. Szabłowski (2017) zastanawia się, czy metody samodoskonalenia się mogą być formą artystyczną? Muzea i galerie zmieniają swoją działalność, której istota do tej pory tkwiła w celebrowaniu wyjątkowych jednostek i ich dzieł, które były pokazywane publiczności. Dzisiaj publiczność to nie tłum, a zbiór indywidualnych odbiorców, z których każdy jest intensywnie zainteresowany sobą - nie chce już tylko ograniczać się do celebrowania artysty geniusza, ale chce z wizyty w muzeum/galerii wynieść „coś konkretnego” dla siebie. To „coś” nie ogranicza się tylko do sfery intelektu, ale także ciała i jego doskonalenia: sport, medytacja, praca nad ciałem i duchem, relaksacja, zdrowie. Instytucje sztuki eksperymentują więc z formą ekspozycji, zrzucając z siebie skojarzenie z elitaryzmem, otwierają się na każdego odbiorcę. „Do instytucji sztuki można zaprosić publiczność na lekcję parkour lub frisbee, lub na jogę (...). To dobre propozycje; ćwicząc jogę, czujemy, że wreszcie robimy w instytucji coś dla siebie - i że instytucja w końcu zajmuje się nami, a nie swoimi dyskursami, które usiłuje nam wcisnąć” (Szabłowski, 2017). 


\section{ZAKOŃCZENIE: PEDAGOG WOBEC POSZERZONEGO POLA SZTUKI}

Obserwując, jak zmienia się sztuka oraz jak na tę zmianę reagują instytucje sztuki, warto zadać pytanie, czy na tę zmianę reaguje także środowisko pedagogiczne? Polska teoria wychowania estetycznego, sięgająca lat 60. XX wieku, została ukształtowana w czasach, kiedy opisywane tutaj formy artystycznego wyrazu dopiero kiełkowały (albo nie było ich wcale). Sztuka współczesna mocno wykracza poza pojęcie sztuki i piękna, do których dotychczas odnosiła się teoria wychowania estetycznego (Pankowska, 2013, s. 171). Z tego względu w dyskursie pedagogicznym słychać głosy odmawiające współczesnym działaniom artystycznym wychowawczego potencjału. Z drugiej strony pojawiają się także głosy krytyczne wobec tradycyjnie ujmowanego wychowania estetycznego (Kwiatkowska-Tybulewicz, 2016, s. 13-14). W kontekście skądinąd szczytnych idei, które stanowiły podłoże polskiej teorii wychowania estetycznego, niezbędne jest jednak jej uwspółcześnienie i reinterpretacja. Krystyna Pankowska zwraca uwagę na fakt, że współczesne wychowanie estetyczne powinno przebiegać wielotorowo i wielozadaniowo, w kontekście trzech płaszczyzn czasowych: przeszłości (sztuka kanoniczna), teraźniejszości (sztuka współczesna i kultura popularna) oraz przyszłości (przestrzeń wirtualna i nowe media jako szansa wychowania estetycznego) (Pankowska, 2013, s. 179). Pewną propozycją zintegrowania sztuki i pedagogiki w optyce innej niż ta opisywana w kontekście tradycyjnej teorii wychowania estetycznego może być perspektywa pedagogiki krytycznej (Kwiatkowska-Tybulewicz, 2016). Obserwując dzisiejsze akcje artystyczne szczególnie interesująca wydaje się idea sztuki-jako-pedagogiki, warta zgłębienia przez środowisko pedagogów i edukatorów artystycznych.

Zaprezentowane w tekście próby odpowiedzi artystów na tęsknotę człowieka współczesnego za żywym doświadczeniem są tylko wycinkiem tego, co ma do zaproponowania odbiorcy świat sztuki na początku XXI wieku. Pisząc o kategorii doświadczenia, nie można nie przywołać Deweya, który za podstawę i punkt wyjścia książki Art as Experience przyjął przekonanie o jak najściślejszym powiązaniu sztuki i życia. W centrum pedagogicznych i artystycznych zainteresowań Deweya znalazła się kategoria doświadczenia, a atrybutem sztuki ujmowanej jako doświadczenie - jej charakter zintegrowany, łączący doznanie i działanie, proces i wytwór. Istotą doświadczenia była dla Deweya jedność zmysłów, potrzeb, odruchów i działań. Irena Wojnar, we wstępie do polskiego wydania Sztuki jako doświadczenia (Dewey, 1975), stwierdza zatem, że Deweyowi bliska byłaby „sztuka typu happeningowego, nieustannie odnawiana w aktach rekreacji, sztuka prowadząca do zatarcia granic między dziełem a odbiorcą, między celowością 
artystycznego spełnienia a przeżyciem odbiorcy” (Wojnar, 1975, s. 31). Może przypadłaby mu zatem także do gustu idea fitness w sztuce...

\section{Bibliografia}

Atkinson, D. (2011). Art, equality and learning: Pedagogies against the State. Rotterdam: Sense Publishers.

Bishop, C. (2015). Sztuczne piekła. Sztuka partycypacyjna i polityka widowni. Warszawa: Fundacja Nowej Kultury Bęc Zmiana.

Carlson, M. (2007). Performans. Warszawa: Wydawnictwo Naukowe PWN.

Dewey, J. (1975). Sztuka jako doświadczenie. Wrocław: Zakład Narodowy im. Ossolińskich. Eisner, E.W. (2004). What can education learn from the arts about the practice of education? International Journal of Education \& the Arts, 5 (4). Pobrane z: http://www.ijea.org/ v5n4/index.html

Fischer-Lichte, E. (2008). Estetyka performatywności. Kraków: Wydawnictwo Księgarnia Akademicka.

Kurz, I., Kwiatkowska, P., Szcześniak, M., Zaremba, Ł. (red.). (2017). Kultura wizualna w Polsce. T2. Spojrzenia. Warszawa: Fundacja Nowej Kultury Bęc Zmiana - Instytut Kultury Polskiej UW.

Kwiatkowska-Tybulewicz, B. (2016). Wychowawcze aspekty sztuki współczesnej. Z perspektywy pedagogiki krytycznej. Warszawa: Wydawnictwa Uniwersytetu Warszawskiego.

Lepsza ja (2017), materiały promocyjne. Pobrane z: https://zacheta.art.pl/pl/wystawy/ lepsza-ja.

McKenzie, J. (2011). Performuj albo... Od dyscypliny do performansu. Kraków: Universitas.

O’Neill, P., Wilson, M. (2010). Curating and Educational Turn. London: Open Editions and de Appel.

Pankowska, K (2013). Kultura - sztuka - edukacja w świecie zmian. Warszawa: Wydawnictwa Uniwersytetu Warszawskiego.

Rogoff, I. (2008). Turning. E-flux Journal. Pobrane z: https://www.e-flux.com/journal/00/68470/turning/.

Sienkiewicz, K. (2017). Patriota wszechświata. O Pawle Althamerze. Kaków-Warszawa: Wydawnictwo Karakter. Muzeum Sztuki Nowoczesnej w Warszawie.

Sontag, S. (2009). Świat obrazów. W: S. Sonntag, O fotografii. Tłum. S. Magala. Kraków: Karakter.

Szabłowski, S. (2017). Fitness w sztuce. Dwutygodnik.com. Pobrane z: https://www.dwutygodnik.com/artykul/7319-fitness-w-sztuce.html.

Szcześniak, M. (2016). Normy widzialności. Tożsamość w czasach transformacji. Warszawa: Fundacja Nowej Kultury Bęc Zmiana - Instytut Kultury Polskiej UW.

Szlendak, T. (2013). Kultura nadmiaru w czasach niedomiaru. Kultura współczesna, 1 (76), s. 7-26.

Wojnar, I. (1975). Sztuka jakością życia. W: J. Dewey, Sztuka jako doświadczenie. Wrocław: Zakład Narodowy im. Ossolińskich. 